Portland State University

PDXScholar

$12-2007$

\title{
From Pork to Kapores: Transformations in Religious Practice Among the Jews of Late Imperial Kiev
}

\author{
Natan Meir \\ Portland State University, meir@pdx.edu
}

Follow this and additional works at: https://pdxscholar.library.pdx.edu/judaic_fac

Part of the European History Commons, History of Religion Commons, and the Jewish Studies

Commons

Let us know how access to this document benefits you.

\section{Citation Details}

Meir, Natan (2007) From pork to Kapores: transformations in religious practice among the Jews of late imperial Kiev. Jewish Quarterly Review, 97 (4), 616-645.

This Article is brought to you for free and open access. It has been accepted for inclusion in Judaic Studies Faculty Publications and Presentations by an authorized administrator of PDXScholar. Please contact us if we can make this document more accessible: pdxscholar@pdx.edu. 


\title{
From Pork to Kapores: Transformations in Religious Practice among the Jews of Late Imperial Kiev
}

\author{
NATAN MEIR
}

SCHOLARSHIP ON THE HISTORY of imperial Russian Jewry has paid scant attention to the religious practices of Jews, often assuming a monolithic traditionalism on the part of most Jews alongside a widespread secularism among acculturated, nationalist, and socialist Jews. Several isolated articles have probed the question of religious reform in the Russian Empire, often looking for ideologically motivated religious change, or reform within institutions such as synagogues. ${ }^{1}$ Twenty years ago, Michael Meyer called for research on the topic, yet we still know little about

I would like to dedicate this article to the memory of Margarita Blank, whose life embraced both a great love for Russia and its culture and a passion for Judaism and the Jewish people. I would also like to thank the many colleagues and friends whose helpful comments were invaluable in the writing of this article. Research for this article was supported in part by a grant from the British Academy.

1. See Mikhail Polishchuk, "Was There a Jewish Reform Movement in Russia?" Shvut 8.24 (1999): 1-35; Mikhail Beizer, "Religious Reform: An Option for the Jews of the Russia in the First Quarter of the Twentieth Century? Example of St. Petersburg-Leningrad," Proceedings of the Twelfth World Congress of Jewish Studies, Division B (Jerusalem, 2000): 199-208. A sophisticated, overarching analysis can now be found in Michael Meyer, "Religious Reform," The YIVO Encyclopedia of Jews in Eastern Europe (sample article), <www.yivo.org/publications/index .php >. This article will not touch upon religious reform in the Kingdom of Poland, on which see Stephen Corrsin, "Progressive Judaism in Poland: Dilemmas of Modernity and Identity," in Cultures and Nations of Central and Eastern Europe: Essays in Honor of Roman Szporluk, ed. Z. Gitelman (Cambridge, Mass., 2000), 89-99; Gershon Bacon, "Kefiyah datit, hofesh bituy ve-zehut yehudit modernit be-folin: Y"L Perets, Shalom Ash ve-sha aruriyat ha-milah be-varshah, 1908," in Studies in East European Jewish History and Culture in Honor of Professor Shmuel Werses, ed. D. Assaf et al. (Hebrew; Jerusalem, 2002), 167-85.

The Jewish Quarterly Review (Fall 2007)

Copyright (C) 2007 Center for Advanced Judaic Studies. All rights reserved. 
actual patterns of religious observance or changes in those patterns. ${ }^{2}$ This article attempts to take a deeper look into the many facets of Jewish religious life, examining personal practice, synagogue membership and attendance, and education, and to chart and explain the changes in that life over the half-century of Jewish settlement in late imperial Kiev. To illuminate the issues raised by the study of Kiev Jewry, comparisons will be drawn with contemporaneous Jewish communities in the Russian Empire. The following pages will reveal that the religious practices of the Jews of nineteenth-century Russia were not free from contradiction or idiosyncracy, and that many Russian Jews, whether rich or poor, adapted to the modern urban environment in an unselfconscious manner that was quite unlike the rational religious choices of Jewish intellectual elites in Western Europe. This meant that secularization, though often increasing from generation to generation, was by no means a simple process or a straightforward journey from piety to irreligion. The appeal of modernity and its ways were strong, but so were the weight of Jewish tradition and the legacy of Jewish civilization - and many Jews felt compelled to blend elements of both worlds in their lives. Most Jews chose neither fundamentalist piety nor radical secularism, but something in between.

Kiev is appropriate for this type of study not because it was typical (though in many ways it was similar to other big cities with large Jewish populations) but because communal controls were particularly weak while official residence restrictions - and the character of the city itselfgave Kiev's Jewish population a unique cast. Jewish life in a metropolis is always bound to be somewhat freer in spirit than in a small town, but Kiev was known for its dearth of the mainstays of Jewish religiosity: educational institutions, synagogues, and rabbis. Government restrictions and supervision of Jewish life (which became increasingly severe in the last decades of the tsarist regime) ensured that only specific categories of Jews would be allowed to settle in Kiev and that freedoms of all kinds would not be taken for granted. Jewish education, whether in the form of schools or hadarim, often had to go underground in the face of legislative and police restrictions. The number of officially sanctioned synagogues and prayer houses was circumscribed and thus insufficient for the growing Jewish population of the city. Other than the state rabbi, there were apparently very few "traditional" or "spiritual" (Jukbovnyi) rabbis in

2. Michael A. Meyer, "The German Model of Religious Reform and Russian Jewry," in his Judaism within Modernity: Essays on Jewish History and Religion (Detroit, 2001), 278-303. 
Kiev throughout the entire period in question. Finally, the official Jewish communal board was made a branch of the Kiev municipality in the 1890s, extending the long arm of the state even further into internal Jewish affairs. Nowhere in the Russian Empire was such a large Jewish population subject to such restrictions.

At the same time, residence requirements and the particular attractions of Kiev contributed to the somewhat eclectic makeup of the city's Jewish community: wealthy merchants and industrialists concentrated in the sugar trade, the economic engine of the Southwest region; upwardly mobile clerks, bookkeepers, and shopworkers legally "attached" to their magnate employers in order to attain legal residence in Kiev; brokers, agents, and speculators (often without residence permits) trying to make a quick ruble in Kiev's fast-paced commodities and properties markets; and large numbers of impoverished artisans and students. Kiev's central geographical location also meant that diverse Jewish migrants came from many parts of the Pale of Settlement: Litvaks and Ukrainian Jews, misnagdim and Hasidim, yishuvnikes (village Jews) and Jews from the large market town. Finally, its proximity to the heartland of compact Jewish settlement meant that Jews could easily travel back and forth between the bustling city and the sleepier stetetekh, which could serve both to soften and to underscore the differences in Jewish communal and religious life in the two settings. Thus, Kiev was uniquely both a central hub attracting thousands of Jews a year from the surrounding, densely Jewish provinces and a frontier city in which one had to make a conscious effort to settle-hence its self-selecting Jewish population. ${ }^{3}$

Many of the migrants who chose to come to Kiev were ready to leave the tightly regulated community of the shtetl and - though most were simply looking for a better living - perhaps even seek a place where they could experiment with different ways of being Jewish. Certainly, in the last few decades of the ancien régime, Kiev was known as a city with a vibrant and diverse array of Jewish institutions and communities, and religious conformity was not necessarily a requirement for belonging. Depending on the original intentions of the migrant when choosing Kiev as a destination and his or her experiences upon arrival, the changes in religious practice discussed in the following pages were sometimes conscious

3. Steven Zipperstein notes that "traditional values tended to weaken" in frontier settings; the "traditional institutions, powerful sanctions, and respected authorities" that were absent in Odessa were also to a certain extent missing in Kiev, though - given Kiev's geographical location - physically closer. Steven J. Zipperstein, The Jews of Odessa: A Cultural History, 1794-1881 (Stanford, Calif., 1985), 36. 
but were likely just as often made in an unpremeditated fashion, one of only many transformations that were part of the development of a modern Russian Jewish identity. Metamorphoses in religious life were also due in part to external pressures, as, for example, when there were not enough legal synagogues for all the Jews in a given neighborhood.

\section{RELIGIOSITY AMONG RUSSIAN JEWS}

The extent of religiosity among Russian Jews in the middle decades of the nineteenth century is very difficult to gauge. In general, there is no reason to doubt the overall impression that Russian Jewry was still largely "traditional," that is, Jewish life still centered around the synagogue and the house of study, the Sabbath and festival cycles, and pious observance of the lifecycle and ritual commandments (including those related to marriage and dress). A life devoted to Talmud study was held up as the ideal for men, while a pious Jewish woman looked to her women's Bible and devotional to help her lead a God-fearing life and merit reward in the world to come. ${ }^{4}$ At the same time, Iulii Gessen, one of the fathers of Russian Jewish history, noted that modernity began rapidly to encroach upon traditional life as early as the 1850 s, a supposition supported by anecdotal evidence such as that related by Pauline Wengeroff in her Memoirs of a Grandmother. ${ }^{5}$ Wengeroff recalls that her husband, disillusioned with Hasidism and living in a wealthy family that had frequent interactions with non-Jews, began to throw off some traditional ways and slowly take on the trappings of the modern world. ${ }^{6}$ That Khonon Wengeroff was the son of an otkupshchik (holder of a state liquor monopoly) is not a surprise, given other kinds of evidence we have about

4. Jacob Katz's Tradition and Crisis: Jewish Society at the End of the Middle Aged (New York, 1993) is the classic depiction of life in early modern Ashkenazic communities. For an idealized portrait of small-town Jewish life in Eastern Europe, see Mark Zborowski and Elizabeth Herzog, Life Io with People: The Culture of the Shtetl (New York, 1952). Shaul Stampfer has sketched various aspects of traditional Jewish society in a number of articles; see, for example, Shaul Stampfer, "What Did 'Knowing Hebrew' Mean in Eastern Europe?" in Hebrew in Asbkenaz: A Language in Exile, ed. L. Glinert (New York, 1993), 129_40; "Gender Differentiation and Education of the Jewish Woman in Nineteenth-Century Eastern Europe," Polin 7 (1992): 187-211; and "Heder Study, Knowledge of Torah and the Maintenance of Social Stratification in Traditional East European Jewish Society," Studies in Jewish Education 3 (1988): 271-89. For Jewish family life, see ChaeRan Y. Freeze, Jewish Marriage and Divorce in Imperial Russia (Hanover, N.H., 2002), 11-50.

5. Iulii Gessen, Istorïa evreiskogo naroda v Rossï (Leningrad, 1927), 2:181-82.

6. Pauline Wengeroff, Rememberings: The World of a Russian-Jewish Woman in the Nineteenth Century, trans. H. Wenkart (Potomac, Md., 2000), 156, 164-65, 174. 
the modernizing ways of such Jewish concessionaires in this period. Wengeroff quotes a folk song about the otkupsbchiki which describes them shaving their beards and eating without first ritually washing their hands, both clear departures from halakhah. Steven Zipperstein has shown that, swept up in the ideology of the Haskalah as well as the more mundane but no less influential current of embourgeoisement, Jewish merchants and businessmen in Odessa adapted some of the cultural patterns of the surrounding cosmopolitan society to fit the contours of their own, still distinctively Jewish, lives. ${ }^{7}$ Modern lifestyles were even beginning to encroach upon Jewish life in stetlekh, though they faced stiff opposition. In 1872, for example, the Jewish communal elders of the Lithuanian town of Telz (Tel'she) refused to hire a cantor because he had purportedly married his wife out of love rather than through an arranged match; moreover, his wife was said to wear "fashionable" clothing. ${ }^{8}$ Thanks to ChaeRan Freeze's work on the Jewish family, we now know that traditional patterns of marriage and divorce started to change in the mid-nineteenth century, inviting a host of responses from both the government and Jewish leadership. ${ }^{9}$ The most hospitable terrain for a non-normative Jewish lifestyle were regions with low Jewish population density, areas of new or recent Jewish settlement, and/or big cities - in other words, locations characterized by relative anonymity and weak communal controls.

Though there was no ideologically driven movement for religious reform as existed in Germany, individual Russian Jews raised their voices at various moments in the late imperial period to call for moderate reforms in Judaism, usually in the realm of synagogue practice and decorum. Ioakhim Tarnopol' (1810-1900), an early maskil and cofounder with Osip Rabinovich of the first Russian Jewish organ, Razsvet, urged changes in a number of areas of Jewish religious life in his Attempt at Contemporary and Cautious Reform in the Sphere of Judaism in Russia (1868) and even introduced the possibility of government-supervised consistor-

7. Zipperstein, The Jews of Odessa; idem, "Haskalah, Cultural Change, and Nineteenth-Century Russian Jewry: A Reassessment," Journal of Jewish Studies 34.2 (1983): 191-207.

8. Vestnik russkikh evreev, August 9, 1872, no. 6, col. 108-9, cited in 'Azriel Shohat, "Ha-hanhagah be-kehilot Rusyah "im bitul ha-kahal," Toìon 42.3-4 (1977): 168. All contemporary periodical sources cited in this article are dated according to the Julian calendar in use in the Russian Empire, which in the nineteenth century was twelve days behind the Western Gregorian calendar, and in the twentieth century thirteen days behind.

9. Freeze, Jewioh Marriage and Divorce, esp. chaps. 3-5. 
ies on the French model. ${ }^{10}$ In the same year that Tarnopol's work was published, Moses Leib Lilienblum wrote an essay in the Hebrew-language Ha-melits in which he advocated moderate changes in Jewish law and custom - not for their own sake, but to reestablish the connection between Jewish youth and Judaism so that the next generation would not be completely disconnected from Jewish tradition. ${ }^{11}$ Lilienblum's articles sparked a literary debate about reform lasting several years which included discussions of the sacrosanct status of custom (minhag) and of the state of Jewish education in Eastern Europe. ${ }^{12}$ Another participant in this debate was the maskil and Hebrew poet Y. L. Gordon, who in waging his own battle against the forces of obscurantism within Russian Jewry criticized not the Talmud but the superstitions and small-mindedness of contemporary rabbis and argued for religious reform as a solution to the Jewish question in Russia. ${ }^{13}$ Only a small minority of rabbis was open to the ideas of the Haskalah and certain aspects of its critique of traditional Jewish society, though even the most moderate among them rejected anything more than minor changes in halakhah. ${ }^{14}$ Indeed, a pair of religious controversies in the mid-1870s showed just how far most circles of Russian Jewry were from the reforms of Western Europe: the disputants argued over the permissibility of etrogim (citrons) from Corfu, a halakhic question revolving around whether the fruit had been grafted onto another tree, as well as whether a new commentary could be published in the traditional format used for printing the Talmud. ${ }^{15}$

10. Joachim Tarnopol, Opyt sovremennoi i osmotritel'noi reformy v oblasti iudaizma - Rossï: razmysblenüa o vnutrennem $i$ vneshnem byte russkikh evreev (Odessa, 1868), 20 and 37. See also Zipperstein, The Jews of Odessa, 110-12, and Evreiskaia entsiklopediia [EE], s.v. "Ioakhim Tarnopol."

11. Meyer, "The German Model of Religious Reform," 295; Michael Stanislawski, For Whom Do I Toil? Judab Leib Gordon and the Crisis of Russian Jewry (Oxford, 1988), 91.

Lilienblum's fears were corroborated by contemporary accounts reporting the widespread secularization of Jewish university students; see Meyer, "The German Model of Religious Reform," 293-96. Lilienblum's essay, entitled "Orhot baTalmud" (The Ways of the Talmud), was published in Ha-melits 8 (1868), nos. 13, $16,18,21,24,25,27$, and 29.

12. Yosef Salmon, "Orthodox Judaism in Eastern Europe," in The Gaon of Vilnius and the Annals of Jewish Culture: Materials of the International Scientific Conference, Vilnius, September 10-12, 1997, ed. I. Lempertas ([Vilnius], 1998), 105-11.

13. Stanislawski, For Whom Do I Toil?, chaps. 5-6.

14. See Joseph Salmon, "Enlightened Rabbis as Reformers in Russian Jewish Society," in New Perspectives on the Haskalah, ed. S. Feiner and D. Sorkin (London, 2004); S. Tsinberg, "Reformistskoe dvizhenie v Rossii," EE.

15. Salmon, "Orthodox Judaism," 113-14. 
In the early twentieth century, N. A. Pereferkovich (1871-1940), a university-trained expert on and translator of rabbinic literature, was also an unyielding critic of the traditional rabbinate. Pereferkovich called attention to the lack of secular knowledge, ignorance of European languages, and disconnectedness with the real lives and problems of Russian Jews that most "spiritual rabbis" displayed. Calling the laws of kasbrut "culturally repugnant," "religiously useless," and "socially and economically injurious," he urged the study of the sacred texts of Judaism in Russian translation so that they would be accessible to the majority of Jews. ${ }^{16}$ In a manner reminiscent of the theorists of Reform and PositiveHistorical Judaism, Pereferkovich compared medieval customs unfavorably with biblical and talmudic laws and recommended a purification of the dross from Jewish practice leading to a return to pure Judaism closer to the religion of antiquity. ${ }^{17}$

Advocates of reform were few, but they had a willing partner in the tsarist government, though they did not always agree on either the ends or the means of reform. When approaching the project of the amelioration of the Jews in the mid-nineteenth century, the Russian state came to the conclusion that the Jews could only be reformed through their religion, which encompassed all aspects of Jewish life. Innovations such as the Rabbinic Commission, the official rabbinate, and state-sponsored Jewish schools were attempts by the government to modernize Judaism and its institutions so as to encourage the integration of Jews into Russian imperial society and, it was hoped, their transformation into productive subjects. ${ }^{18}$ To be sure, these reforms were not aimed primarily at Jewish religious practice but rather at the manner in which Judaism, rabbinic literature, and halakhah were taught, applied, and enforced. ${ }^{19}$ But because Jewish law, education, and practice are in day-to-day actuality im-

16. Naum Abramovich Pereferkovich, Religioznye voprosy u sovremennykh evreev - Rossï: Razbor "zakliuchenï" Osobago S"iezda pri Ravvinskoi kommissï 1910 g. (St. Petersburg, 1911), 25, 45. See also EE and Encyclopedia Judaica.

17. See, for example, his explanation of erusin (betrothal) and nisuin (marriage) and their "corruption" in the Middle Ages, p. 66. The editors of Evreiskaia entsiklopedïa noted that Pereferkovich was "also known for his unsuccessful attempt at reform in the sphere of Jewish religious life" (s.v. "Pereferkovich").

18. See Michael Stanislawski, Toar Nicholas I and the Jews: The Transformation of Jewish Society in Rusdia, 1825-1855 (Philadelphia, 1983), 104-9; Freeze, Jewish Marriage and Divorce, 83-130.

19. A notable exception was the decree outlawing traditional Jewish dress. See Stanislawski, Tsar Nicholas, 44, 47. See also EE, s.v. "Odezhda," and Iu. Gessen, "Bor'ba pravitel'stva s evreiskoi odezhdoi v Imperii i Tsarstve Pol'skom," Perezbitoe 1:2, 10-18. 
possible to disentangle from each other, the changes did have a slow but very real influence on Jewish life. As Stanislawski and Freeze have shown, these new creations, though often rejected by many Jews, eventually had a major impact on the modernization of Russian Jewry. ${ }^{20}$ While Crown rabbis were hardly in a position to implement reforms, and were even - according to some reports - rejected out of hand by the communities in which they were placed because of their ritual laxity or even outright rejection of certain ritual commandments, their positions of influence and prominence, especially in larger cities, must have had some impact on their perception by the larger, non-maskilic Jewish community. ${ }^{21}$

Another approach to "reform" in the Russian Empire were Germanstyle choral synagogues established in the empire's largest cities, which tinkered with synagogal and liturgical customs in order to enhance the decorum of the worship service but rarely introduced major innovations along the lines of those seen in Germany. But for the occasional exclusion of piyutim (liturgical poems), changes in the prayerbook were rarely made. ${ }^{22}$ In a natural coming together of grassroots and governmental reform efforts, many of the rabbis at these choral synagogues were graduates of state rabbinical seminaries. ${ }^{23}$ Still, novelties such as sermons in Russian or Polish, cantors and choirs singing Western-style music, and confirmation ceremonies were viewed with curiosity by most Russian Jews, and they remained confined to large cities such as St. Petersburg, Odessa, Riga, Warsaw, and, as we will see, Kiev. ${ }^{24}$ Even in the newly

20. See also Eli Lederhendler, The Road to Modern Jewish Politics: Political Tradition and Political Reconstruction in the Jewish Community of Tsarist Rusia (New York, 1989), chaps. 4-5; S. Tsinberg, "Reformistskoe dvizhenie v Rossii," EE.

21. See, for example, Freeze, Jewish Marriage and Divorce, 100; Iu. Gessen, "Ravvinat," EE; 'Azriel Shohat, Mosad ba-rabanut mi-ta'am be-Rusyah (Haifa, 1975), 96. Mordecai Zalkin argues that most of the graduates of the state rabbinical seminaries were actually not as ignorant of Judaism or heretical in their actions as they were later portrayed. Mordekhai Zalkin, "The Vilna Rabbinical Seminary -Between Image and Reality” (Hebrew), Gal-Ed 14 (1995): 59-72.

22. Stanislawski, Tuar Nicholas, 138-41; Meyer, "The German Model of Religious Reform," 280-83, Polishchuk, "Jewish Reform Movement," 3-4; Nathans, Beyond the Pale, 155-64; Alexander Guterman, "The Origins of the Great Synagogue in Warsaw on Tłomackie Street," in The Jews in Warsaw: A History, ed. W. T. Bartoszewski and A. Polonsky (Oxford, 1991), 181-211.

23. S. Tsinberg, "Reformistskoe dvizhenie v Rossii," EE; Stanislawski, Toar Nicholas, 141.

24. One smaller settlement with a choral synagogue was Berdichev, not a large city by any measure but with a Jewish population in 1897 of almost 42,000, considerably larger than the 32,000-strong Jewish community of Kiev. 
settled Russian South, where such innovations were somewhat more widespread and were even adopted by some traditionalists, the trend never became a discrete movement with a developed ideology. ${ }^{25}$

\section{JEWISH SETTLEMENT IN KIEV}

Jews had lived in Kiev on and off since the Middle Ages, but for much of the early modern period Jews were only permitted to enter the city for brief periods to trade. In the early years of Russian rule in the late eighteenth and early nineteenth centuries, Jewish settlement was permitted, but in 1827 Nicholas I approved an expulsion order of Jews from the city, which was not rescinded until the early years of the reign of the Alexander II. ${ }^{26}$ Kiev was officially opened to limited Jewish settlement in 1861, and certain categories of Jews such as merchants, artisans, and pupils in educational institutions (and their families) were permitted to reside in the city. ${ }^{27}$ Most Jews who lived in Kiev fell into the category of "temporary residents," but a widespread culture of bribery meant that hundreds or even thousands of illegal Jews could easily spend months or years at a time in the city without trouble from the police. ${ }^{28}$

Kiev as a whole grew rapidly in the 1860 s and 1870 s, becoming the dominant center of the developing agricultural and industrial sectors of the Russian Southwest (Right-Bank Ukraine and Chernigov and Poltava provinces), as well as an important hub for finance, administration, and education. The Kiev Commodities Exchange was established in 1873, while the annual Contract Fair continued to be a mainstay of the Kiev economy and a contributing factor to its rapid growth. ${ }^{29}$ Its Jewish popu-

25. Here I differ with Polishchuk, who argues that the "diverse forces" contributing to the reform trend "constituted a movement"; Polishchuk, "Jewish Reform Movement," 32. See also his Evrei Odessy i Novorossü: Sotsial'no-politicheskaia istorïa evreev Odessy i drugikh gorodov Novorossï, 1881-1904 (Jerusalem and Moscow, 2002).

26. Evreiskaia entsiklopedïa, s.v. "Kiev"; Jewish Encyclopedia, s.v. "Kiev"; Encyclopedia Judaica, s.v. "Kiev"; Michael Hamm, Kiev: A Portrait, 1800-1917 (Princeton, N.J., 1993), 3-17, 117-21; M. I. Kulisher, "Evrei v Kieve: Istoricheskii ocherk," Evreiskaia starina 5 (1913): 351-66, 417-38; Iulii Gessen, "Getto v Rossii," Evreiskii mir 13 (April 1, 1910); idem, "Mnogostradal'naia obshchina," Evreiskii mir 22 (September 25, 1910).

27. M. I. Mysh, Rukovodstvo k russkim zakonam o evreiakh (St. Petersburg, 1892), $242-51$.

28. M. I. Kulisher, "Evrei v Kieve: Istoricheskii ocherk," Evreiskaia starina 5 (1913): 430-33.

29. V. E. Dement'eva, ed., Istorïa Kieva (Kiev, 1963), 1:349. 
lation also grew quickly as changes in the traditional economy and a demographic explosion among Russian Jews (which was already several decades old) spurred Jews to look for new opportunities and contexts in which to make a living. These they found in thriving new communities such as Odessa, Ekaterinoslav, and Kiev, located in the economically flourishing southern and southwestern provinces. Kiev grew rapidly in the post-1861 period, its population almost doubling in the decade between 1864 and 1874, when it reached 124,000, and doubling yet again between 1874 and $1897 .{ }^{30}$ The tremendous flow of migration to the city can be seen in the fact that in 1874 , only 28 percent of its population were natives of Kiev. Indeed, just 45 percent were from the Southwest region, testifying to the geographical diversity of Kiev's new arrivals. ${ }^{31}$

\section{REPORTS OF DEVIANCE}

Evidence about religious observance from the first two decades of Jewish settlement in Kiev is spotty, and much of the reporting tendentious. However, the overall impression is that the small community was fairly traditional, though change was in the air. An 1873 report in the newspaper Kievlianin claimed that most of the shops on Kreshchatik, Kiev's main commercial avenue, were closed on Saturday, but it must be kept in mind that the author's intent was to reveal the extent of Jewish domination of Kiev (the editorial perspective of Kievlianin was one of russification and often Judeophobia). ${ }^{32}$ Around the same time, the Judeophobic A. N. Murav'ev - also set on showing that Kiev was becoming "the capital of the zhidg" - wrote that the Jewish magnates living in the wealthiest parts of the city had still not given up their "pesiki" (a derogatory term for peyes, sidecurls) and "zhid rituals." ${ }^{3}$ Certainly it comes as no surprise that two prominent Jews invited to a celebration hosted by the governor-general of the Southwest region were provided with kosher food. ${ }^{34}$ A correspondent from Kiev to the Yiddish newspaper Kol mevaser wrote in 1870 that

30. Yakov Lestschinsky, "Di idishe bafelkerung in Kiev fun 1897 biz 1923," Bleter far idishe demografie, statistik un ekonomik 5 (1925): 50.

31. Dement'eva, Istorï̈a Kieva, 1:339.

32. Kievlianin, no. 26 (March 1, 1873): 1-2; this phrase was repeated in subsequent years. On Kievlianin, see John D. Klier, "Kievlianin and the Jews: A Decade of Disillusionment, 1864-1873," Harvard Ukrainian Studies 5 (1981), 1, and John Doyle Klier, Imperial Russia's Jewish Question, 1855-1881 (Cambridge, 1995), 182-203.

33. Andrei Nikolaevich Murav'ev, "Zapiska o sokhranenii samobytnosti Kieva (Nachalo 1870-kh gg.)," Iehupets 5 (1999): 265.

34. Ha-melits 47 (December 9, 1865): 714-15. 
even the "enlightened" Jews in Kiev attended synagogue - if not regularly, then at least from time to time. ${ }^{35}$

But the foundations for a next generation of observant Jews in Kiev were shaky. By 1880, there were only four authorized prayer houses in Kiev, and thus most synagogues had to operate clandestinely. ${ }^{36}$ Because of government restrictions on organized Jewish life in Kiev, access to Jewish education was also difficult. Apparently, a good Talmud-Torah lasted in the city until 1878, when it was shut down; thereafter, it operated in a semi-legal limbo, which did not bode well for the quality of pedagogy at the school. Until 1895, men with Kiev residence rights were forbidden from working as melamdim (heder teachers) ${ }^{37}$; according to one cynic, this state of affairs led to an unregulated situation where anyone could try to pass himself off as a melamed, spelling doom for the quality of the city's hadarim. ${ }^{38}$ Thus, other than the wealthiest families who could afford to hire private tutors for their children, parents moving to Kiev found a city with an abundance of opportunities for secular education for their children but little in the way of Jewish schooling. ${ }^{39}$ Indeed, a correspondent from Kiev in the early 1880s wrote that many Jewish children in the city were educated in non-Jewish institutions, without religious instruction..$^{40}$ The city could certainly never hope to have its own yeshivah. This circumstance undoubtedly had an impact on the Jewish knowledge and perhaps even observance of the next generation of Kiev Jews.

It is perhaps no surprise, then, that we begin to see changes in religious practice on a large scale with the coming of age of the next generation of Kiev Jewry in the 1880 s and 1890s. Indeed, as early as the late 1870 s one new arrival to the city, Yekhezkel Kotik, was surprised from the very start by the "licentiousness" (oyslasnkeyt) that cohabited so easily with superstition among Kiev Jews. Amazingly, Kotik paints a picture of Has-

35. Kol mevaser, no. 42 (October 22, 1870): 309-10.

36. Derzhavnyi arkhiv Kievskoï oblasti, f. 1 (Kievskoe gubernskoe pravlenie), op. 336, spr. 6197, ark. 1-4zv.

37. Ha-melits, no. 119 (June 2, 1895).

38. Ha-melits, no. 176 (August 5, 1894).

39. For example, in 1880 the student body of the Third Gymnasium in the Podol district was 30 percent Jewish. Kievlianin 93 (April 25, 1880): 1.

40. Russkii evrei, no. 7 (February 11, 1881); Yehudah Slutsky, Ha-'itonut bayehudit-rusit ba-me'ah ba-tesba-'esre (Jerusalem, 1970). It should be noted that, in addition to the official quotas established in official educational institutions with the introduction of the numerus clausus for Jewish males in universities and gymnasia in the mid-1880s, Jews began to be barred from other kinds of educational facilities on an ad hoc and individual basis. 
idim smoking cigars on the Sabbath while having a Gypsy woman read their palms!41 Kotik, himself a product of a pious hasidic home, criticized Kiev's Hasidim for not truly understanding Hasidism; they believed in its miracles and wonderworking but not the faith, love, and ecstasy that underlay the hasidic way. ${ }^{42}$ Kotik claimed that although there were many Hasidim in Kiev, there were few sttiblekh_but it is impossible to know whether this situation stemmed from the legal restrictions on private prayer quorums or the widespread "licentiousness" he had observed.

Kiev's Jews were certainly not unique in their laxity. Writing of his childhood in Bialystok in the 1870s and 1880s, Yeshaya Heshl Perelstein described Jewish homes where many basic strictures (such as those relating to eating and Sabbath observance) had been dropped. ${ }^{43}$ In 1870 s Odessa "the most sacred rituals were casually ignored and the most stringent prohibitions publicly transgressed," while Warsaw Jewish charities hosted galas where mixed-sex dancing was an unremarkable occurrence. ${ }^{44}$ And Freeze has charted the decline in the late nineteenth century of the observance of Jewish legal requirements associated with marriage and divorce, such as that of halitsab (levirate divorce) and the payment of child support. ${ }^{45}$

Although reports of widespread abandonment of ritual-such as that from a correspondent to the Hebrew newspaper Ha-yom who maintained that "most of this city's Jewish inhabitants have abandoned the Torah" were no doubt exaggerations, we have no reason to doubt his claim that many Jewish shopkeepers kept their businesses open on the Sabbath and Jewish holidays. ${ }^{46}$ The city's Jewish elite, in particular, was noted for its acculturating ways. In 1880, members of the self-proclaimed "educated constituency" of Kiev Jewry petitioned the authorities for permission to

41. Yekhezkel Kotik, Mayne zikhroynes (toveyter teyl) (Warsaw, 1914), 245-46. In a personal correspondence with the author, David Assaf, translator and annotator of Friedmann's memoirs, remarked that although he questions Kotik's reliability on this matter, he has found corroboration of his astonishing account in the works of Yehudah Leib Levin (Yehalel). See Yehezkel Kotik, A Vagabond: The Memoirs of Yehezkel Kotik, ed. and trans. D. Assaf (Hebrew, Tel Aviv, 2005), 183.

42. Kotik, Mayne zikhroynes, 244.

43. Eli Lederhendler, Jewish Responses to Modernity: New Voices in America and Eastern Europe (New York, 1994), 64.

44. Zipperstein, The Jews of Odesda, 131; Piotr Wrobel, "Jewish Warsaw before the First World War," in The Jews in Warsaw, 254.

45. Freeze, Jewish Marriage and Divorce, 241. In Warsaw there were reportedly "demoralised rabbis ... who solemnised fictitious marriages and quick divorces for commercial gain." Wrobel, "Jewish Warsaw," 254.

46. Ha-yom 2.27 (May 21, 1887), cited in Shohat, Mosad ha-rabanut, 184, n. 8. 
open their own synagogue in the center of the city (the synagogue is discussed in greater detail below). ${ }^{47}$ In the mid-1890s we hear accusations that the wealthy elite hired tutors in Jewish subjects for their children for only half the year; another observer remarked cynically that the tutors were hired by the month and fired when the lady of house realized that she needed the money to pay for the extra costs associated with renting a dacha for the summer. ${ }^{48}$ In a feuilleton about the poor state of Jewish education in the Russian Empire, the Hebrew writer Yitshak Yaakov Weisberg, a resident of Kiev, placed part of the blame on the lack of Jewish education for girls, who when they became mothers had nothing to pass on to their sons. ${ }^{49} \mathrm{He}$ referred particularly to the wealthy ladies who adored novels and the theater, and even worse, the social-climbing women who aspired to nobility, for whom one word of French was preferable "to all of Judaism, of which they know nothing." ${ }_{50}$ As in Germany, Jewish women - ostensibly responsible for the religious and moral upbringing of their children - were often blamed for the corruption of Jewish youth. ${ }^{51}$

E. E. Friedmann's memoirs of 1890 s Kiev also portray a city where Jewish observance may have been honored more in the breach, at least in some circles. According to his account, Jewish observance in Kiev could not be neatly categorized; he reported that many Jews picked and chose from traditional rituals, usually observing those that related to major holidays. A Jew might desecrate the Sabbath and eat nonkosher food-even on the Day of Atonement-yet would be careful about kapores, the custom of casting one's sins onto a chicken on the eve of that solemn holiday, or about eating only unleavened food products on Passover. A Jew who ate pork would nonetheless organize a prayer quorum in his house for the High Holy Days. ${ }^{52}$ Much of this kind of behavior he

47. [I. P. Kel'berin,] Desiatiletie Kievskago evreiskago khoral'nago molitvennago doma (Kiev, 1909), 5-6, 9.

48. Ha-melits, no. 112 (May 17, 1894): 4-5; Ha-melits, no. 115 (May 20, 1894): 3 .

49. On secular education for Jewish girls and "the unique role of women as agents of social change in Jewish society," see Iris Parush, Reading Jewish Women: Marginality and Modernization in Nineteenth-Century East European Jewish Society (Lebanon, N.H., 2004), chapter 4.

50. Ha-melits, no. 4 (January 14, 1885).

51. See Paula Hyman, Gender and Asdimilation in Modern Jewish History: The Roles and Representation of Women (Seattle, Wash., 1995).

52. E. E. Friedmann, Sefer ha-zikhronot, vol. 2 (Tel Aviv, 1926), 205. Zipperstein notes similarly erratic behavior in Odessa: "the same individual might fast on a minor holy day and then desecrate the Sabbath." Zipperstein, The Jews of 
observed among the speculators, brokers, and traders who did business at the Kiev commodities exchange; he remarked that their behavior was not motivated by any conscious choice but simply by the fact that they were "free from the yoke of Torah." ${ }^{53}$ Friedmann makes clear his impression that, due to the extremely heterogeneous makeup of Kiev's Jewish population, communal life and controls in the city were very weak. ${ }^{54}$ As in Odessa, the ardor for making money was overwhelming for many, who could not be bothered to be fastidious about religious observance when more important things demanded their valuable time. ${ }^{55}$ Often a compromise worked out with the help of a halakhic loophole - a Christian hired to work in a shop on a Saturday-simply seemed unnecessary after a certain period of time. ${ }^{56}$ Perhaps some Jews' libertinism was linked to the fact that many of them were alone in the city, without family, like Sholem Aleichem's fictional Menakhem-Mendl, who also tries his hand at trading and brokering; many were also young, for who else but a young man without a family to support could take the risk of speculating in Kiev, where a "fortune" could be made one day and lost the next? MenakhemMendl writes to his wife that the sugar traders are "rich as the devil, ride around in carriages, live in dachas in Boiberik, play cards all day long, and have courtasins and conquerbines [ $\left.{ }^{\prime} i c\right] .{ }^{\prime 57}$ In fictional Yehupets, as perhaps in the real Kiev, Jewish mores were somewhat loose: "It's not unusual for a man to throw over his wife for another woman he's fallen in love with, or for a woman to throw over her husband." 58

Even the kosher dietary laws, a pillar of Jewish particularism and identity even for many freethinkers, were not strictly observed by all Kiev Jews. In 1895, a concerned Kiev Jew warned that non-Jews had begun to hire unscrupulous Jews to place a stamp of kashrut on wines that

Odessa, 131. Ruth Abusch-Magder discusses inconsistencies in the observance of kashrut among German Jews in "Eating 'Out': Food and the Boundaries of Jewish Community," Nashim 5 (Fall 2002): 65.

53. Friedmann, Sefer ba-zikbronot, 209.

54. Ibid., 215.

55. See Zipperstein, The Jews of Odessa, 37.

56. An observer of 1905 Warsaw wrote: "It began with a compromise. The owner of a shop was standing there, and the Christian woman hired for Saturday was selling soda water and taking the money. After a few months, this mediation disappeared.” H. Piasecki, “Żydowska Organizacja PPS 1893-1907” (Wrocław, 1978), 192, cited in Wrobel, "Jewish Warsaw," 266.

57. Sholem Aleichem, The Letters of Menakhem-Mendl and Sheyne-Sheynd and Motl, the Cantor's Son, trans. H. Halkin (New Haven, Conn., 2002), 42.

58. Ibid., 48. Peretz Smolenskin describes Odessa's freewheeling Jews in similar terms in his novel Simlat ha-nef. Zipperstein, The Jews of Odessa, 108-9. 
were not in fact kosher for Passover. And, whether out of carelessness or ignorance, Jews were falling for the ruse and buying the wine. The author cautioned the bogus supervisors that they were being watched, but their actions suggest that there were few people in Kiev willing or able to guard against such scams. ${ }^{59}$ Furthermore, though Kiev Jews were still largely Passover-observant, at least some of them were relaxed enough that they found it unnecessary to verify the kashrut supervision on the products they purchased for the holiday. More disturbing for some, a significant number of Kiev's Jewish communal leaders no longer bought kosher meat for their tables, a fact stressed by a local dissident who made public the fact that those very leaders continued to be responsible for allocating the revenues from the kosher meat tax even though they did not pay it themselves. ${ }^{60}$ Though Crown Rabbi Joshua Tsukkerman received ample remuneration from the communal purse, the city's six "spiritual" (traditional) rabbis, complained one observer in 1892, had had their salaries cut completely by the communal leadership. " ${ }^{61}$ " Rabbi' is a dirty word in Kiev," remonstrated the dissident. Thus, yet another challenge was added to the maintenance of proper religious leadership in Kiev - in addition to that posed by residence limitations. ${ }^{62}$

Less surprising, perhaps, are the reports of students and young people transgressing Jewish law, as students were known for their rebellion against tradition and were seldom representative of mainstream trends within the Jewish community as a whole. In 1894, a Mrs. M. Gol'dberg organized a subsidized kosher cafeteria for Kiev's Jewish students who,

59. Ha-melits, no. 68 (March 22, 1895).

60. Central Archives for the History of the Jewish People, Ru 81, Doc. 2: “Tazkir ha-rav ha-Kiyovi A'. Luria' el mo'etset ha-'ir be-Kiyov," November 20, 1903. That this was indeed the case is made clear by a 1906 petition submitted by members of that same elite, which noted that, with a few rare exceptions, prosperous Jews did not eat kosher meat. Tsentral'nyi derzhavnyi istorychnyi arkhiv Ukraïny, Kyiv (TsDIAU) f. 442 (Kantseliaria Kievskogo, Podol'skogo i Volynskogo general-gubernatora), op. 658, spr. 97, ark. 99.

61. Unlike many state rabbis, Tsukkerman, a graduate of the Zhitomir state rabbinical seminary and elected to the post in Kiev in 1859, had received a traditional Jewish education and was reasonably well versed in Jewish law and lore. Though many official rabbis were treated by their Jewish communities as little more than lower-level bureaucrats, those in the newer communities of the southern Pale often had some success in making a place for themselves as organizers of communal affairs, welfare, and charity, as Tsukkerman did quite effectively. Shohat, Mosad ha-rabanut, 56, 58; Freeze, Jewish Marriage and Divorce, 104-5.

62. Ha-melits, no. 290 (December 30, 1892): 5-6. 
according to Ha-melits, had been eating at nonkosher dining halls because of their miserable financial circumstances. ${ }^{63}$ About the same time, a report in the Hebrew press remarked that the Jewish "enlightened youth" (tse irim mitna'orim) of the city usually spent their Sabbath mornings not in synagogues, but in Kiev's cafes. ${ }^{64}$ The fact that this was worthy of acknowledgment in the press is in itself telling, for it means that this type of behavior was still unusual.

Other condemnations in the press of aberration in religious practice including mixed-sex dancing at weddings and the improper observance of some fasts - are also reliable evidence that this behavior was still relatively rare. ${ }^{65}$ But this decade witnessed several cases that were far more serious. In 1896, an apprentice lawyer, Iakov Gol'denveizer, lodged an official complaint against Crown Rabbi Joshua Tsukkerman for refusing to register Gol'denveizer's newborn son in the official metrical books. The reason for Tsukkerman's resistance? Gol'denveizer had not had his son circumcised. The official records do not reveal the motivation for Gol'denveizer's highly unusual action, but it is clear that it was not on medical grounds. And this was not the first such case that Tsukkerman had been faced with: the documents refer to the case of Benedikt Mandel'shtam, who had declined to circumcise his son in $1891 .{ }^{66}$ (A similar case, perhaps the first of its kind in the Russian Empire, is recorded in 1873 in Odessa ${ }^{67}$ ) Far from minor variations in ritual, these cases, while extreme, reveal the extent to which some Jews were willing to jettison traditional practice while at the same time declining to convert to Christianity. Unfortunately, the extant records do not allow us to probe the motivations of the historical actors in these cases, as has been done with excellent effect in the case of German Jews. ${ }^{68}$ We may speculate, however, that these parents hoped to make it easier for their sons to move freely in imperial Russian society without the physical marking - or perhaps any other indicator — that might set them apart as Jews.

63. Ha-melits, no. 34 (February 9, 1895): 2.

64. Ha-melits, no. 198 (August 31, 1894): 2.

65. Ha-melit, no. 28 (February 2, 1896): 4; no. 40 (February 16, 1896): 5. These two items were written by different correspondents.

66. Rossiiskii gosudarstvennyi istoricheskii arkhiv (RGIA) f. 821 (Departament dukhovnykh del inostrannykh ispovedanii MVD), op. 9, d. 46. For a later case in Warsaw, see Gershon Bacon, "Kefiyah datit."

67. RGIA f. 821, op. 81, d. 381.

68. See Robin Judd, "Circumcision and Modern Jewish Life: A German Case Study, 1843-1914," in The Covenant of Circumcision: New Perspectives on an Ancient Jewish Rite, ed. E. Wyner Mark (Hanover, N.H.), 142-55. 


\section{KIEV'S CHORAL SYNAGOGUE}

There is evidence that the Jewish elite of Kiev desired their own prayer house as early as 1867 , only a few years after Jews were officially readmitted to the city. In that year, Crown Rabbi Tsukkerman petitioned for permission to rent a facility "expressly for the Jewish Merchantry" in which the latter could hold services - apparently so they would not have to mix with the poorer artisan folk. ${ }^{69}$ By 1880 , thirty petitioners calling themselves the "educated constituency" of Kiev Jewry were requesting permission to open their own synagogue in the center of the city, where there were already over one hundred Jewish homes. ${ }^{70}$ In addition to the problem of location - most of the petitioners lived in the central districts of the city, too far to walk to the existing prayer houses in the outlying neighborhoods - the request explained that

the internal configuration of the aforementioned prayer houses does not conform to the contemporary religious requirements of educated Jews because of the absence of choral singing and, in general, that order in divine worship which has already been introduced into Jewish prayer houses in several important Russian cities such as Petersburg, Moscow, Odessa, and others. ${ }^{71}$

Choral singing and orderly worship, two elements missing from the services in prayer houses, were construed not only as desiderata of the petitioners but as "requirements." From their perspective, worshipping in a traditional prayer house was no longer a possibility; they had to have their own synagogue. The desire for an orderly and regularized service is remarkably similar to Osip Rabinovich's depiction (written over thirty years earlier) of the reaction of the young maskil to services in the local prayer house: "the very format of the prayers, with violent cries, hand clapping, convulsive movements, without any system, as if in the forest, evoked in us not reverence but horror." 72 Seemingly, little had changed in the traditional Jewish prayer house, prompting the same horrified response in generation after generation of educated Russian Jews.

The petition went on to say that without a modern synagogue, the younger generation, whose members did not attend services at all, "are

69. TsDIAU f. 442, op. 46, spr. 35.

70. [Kel'berin,] Desiatiletie, 5-6, 9.

71. Ibid., 7. The petition is also cited in RGIA f. 821 , op. 8, d. 153, 1l. 7-8ob.

72. Osip Rabinovich, "Novaia evreiskaia sinagoge v Odesse," Sochinenïa (Odessa, 1888), 3:373-74, cited in Stanislawski, Trar Nicholas, 140. 
thus deprived of the moral support that all find in religion and can more easily fall prey to pernicious influences." ${ }^{3}$ We learn, then, that even if the heads of families were attending services at a private home, their children and other younger Jews (students, for example, who were explicitly named in a later petition) were not doing so and evidently had no other consistent or reliable link to Judaism at all. Interestingly, although the early petitions regarding the choral synagogue suggested that Kiev's Jewish elite wanted to distance itself from the Jewish masses, in later decades-after years of acculturation-just the opposite tack was used. Now, proponents of choral synagogues viewed them as tools to bring progressive, acculturated Jews back in touch with Judaism and the Jewish people. Thus, a defender of the soon-to-be-built choral synagogue in Kiev, writing in the Hebrew press in 1896, remarked that the early choral synagogues had been built by modernizing Russian Jews eager to distance themselves from the "backward" ways of traditional synagogues, but the new Kiev synagogue was a reversal of that trend as maskilim returned to their roots, building a synagogue "in order to come closer to the Jews."74

The Choral Synagogue in Kiev, or the Brodskii Synagogue as it was known, was not built until 1898, but those interested in gathering in a European-style house of worship met in rented premises until they were able to secure permission to erect their own building. Like the choral or great synagogues in Warsaw, St. Petersburg, and Odessa, the Brodskii Synagogue in Kiev did not deviate from Jewish religious law, but the changes it made in minhag were significant, especially for Eastern Europe where minhag played a central role in Jewish religious culture. A hired cantor led the services, often with the help of a choir; the rabbi delivered sermons in Russian; the layout of the pews was changed (all seats now faced the eastern wall); and extraneous conversations were banned. ${ }^{75} \mathrm{Un}$ like most Jewish prayer houses, great attention was paid to ensuring that the architecture and decor of the synagogue were both lavish and aesthetically pleasing. One newspaper account gives a hint that, as in Warsaw's Great Synagogue, men called up for honors to the Torah were required to wear black hats. ${ }^{76}$ We do not know whether, as in Odessa's Brodskii Synagogue, medieval piyutim were eliminated from the service;

73. [Kel'berin,] Desiatiletie, 8. Tarnopol, in his Attempt at Contemporary and Cautious Reform, also pointed to the need for services that appealed to Jewish youth. Zipperstein, The Jews of Odessa, 112.

74. Ha-melits, no. 108 (May 17, 1896).

75. See Polishchuk, "Jewish Reform Movement," 32.

76. Ha-melits, no. 223 (October 8, 1891); Guterman 185. 
this would have been a step further in the process of change. ${ }^{77}$ Certainly the synagogue did not go as far in its innovations as some of the more radical synagogues in the Odessa area, such as that of the Society of Jewish Shop Attendants, which featured an organ and a mixed-sex choir on the High Holy Days. ${ }^{78}$

Although details are sketchy, there is evidence that there was some divergence of opinion among the synagogue's members over the tone of the services. Two of the leading voices in the debate were those of Lazar' and Lev Brodskii, sugar barons who numbered among the richest men in the empire and were known as the "kings" of Kiev Jewry because of their preeminent position in the Jewish communal leadership of the city. E. E. Friedmann wrote that Lazar' Brodskii, like his father Israel, was a pious Jew whose philanthropy and public-mindedness were motivated by his wholly traditional desire to do good deeds. ${ }^{79}$ According to this account, Brodskii, who donated the lion's share of the funds for the construction of the Brodskii Synagogue, attempted to instill in it a traditionalist spirit, in apparent opposition to the other members of the board who were proponents of a more formal, decorous German-style Judaism. In Friedmann's Zionist-influenced analysis, the latter eventually won out over the "living national spirit," and the synagogue became a "factory" for the recitation by so-called assimilators of the mourner's kaddish and dry ceremonies on Sabbath and festivals. Lazar's efforts seem to demonstrate that the physical trappings of a choral synagogue did not necessarily mean that the services themselves would be "modernized" - though in this case, that seems to have been their fate.

Lev Brodskii had an answer to the avant-garde synagogue sponsored by his more prominent brother - another, more traditionalist synagogue right next door. Several years after the opening of the Brodskii Synagogue, he endowed what came to be called the "Merchants' Synagogue" immediately adjacent to the one that his brother had founded but apparently much closer in aura (and in its lack of decorum) to a traditional prayer house. ${ }^{80}$

Lev was not the only Kiev Jew to respond negatively to the new synagogue. Commenting on local religious life in 1885, Israel Darewskii noted that since most of the city's Jews were Hasidim, they were opposed to a choral or "reformed" (metukan) synagogue in the city. ${ }^{81}$ The next year,

77. Polishchuk, "Jewish Reform Movement," 3.

78. Ibid., 16.

79. Friedmann, Sefer ha-zikbronot, 213.

80. Ibid., 225-29.

81. Ha-melits, no. 6 (February 21, 1885): 88-93. 
Darewskii commented acidly that the "enlightened" Jews of Kiev only attended synagogue three days a year, on the high holidays, and many were not even present for the New Year because they had not yet returned from their summer homes. A few more came back for the yizkor memorial services conducted on the Shemini Atseret holiday because, according to Darewski, "they have decided that yizkor is more important than prayer." 82 A few years later, another correspondent remarked that he had heard many people speaking ill of the choral high holiday services organized by the notables. ${ }^{83}$

At the same time, the grandiose building clearly piqued the curiosity of both Jews and non-Jews; after the gala dedication in 1898, the doors were opened to the masses gathered outside so they could enter and marvel at the architecture and craftsmanship. ${ }^{84}$ The handsome exterior concealed a soaring sanctuary with fittings of the finest materials as well as a chapel, library, bridal chamber, meeting room, and a room for choir practice. The building was also centrally heated and ventilated using state-ofthe-art technology. ${ }^{85}$ In Odessa, several synagogues (among them even an "Orthodox" prayer house) copied innovative elements of that city's choral synagogue such as its choir and seating arrangement. ${ }^{86}$ The same may have been true of Lev Brodskii's Merchant Synagogue in Kiev.

To many Jews, however, the innovations of the choral synagogues were departures from the norm, as were the new burial paraphernalia introduced by the Kiev hevrab kadisha' (burial society) soon after its 1892 "takeover" from traditionalists by members of the acculturated elite, a move that had the sanction of Crown Rabbi Joshua Tsukkerman. In this area Kiev was following a trend begun two decades earlier in Odessa, which had subsequently spread to many cities in the South. ${ }^{87}$ The new options were meant to satisfy the modern tastes of the acculturated elite as well as the requirements of tradition: coffins with black writing on a white background, instead of plain wooden boxes; a hearse drawn by black horses; and special mourning garb for the undertakers. (Apparently not everyone would be entitled to such lavish treatment; some or all of these burial extras were dependent on "the honor of the deceased.") While one observer emphasized that the new caskets were not Christian

82. Ha-melits, no. 215 (October 3, 1896): 2.

83. Ha-melits, no. 223 (October 8, 1891): 2.

84. Ha-melits, no. 195 (October 31, 1898): 2.

85. I. Kel'berin, K istorï evreiskago khoral'nago molitvennago doma v Kieve (Kiev, 1909), 18-19.

86. Polishchuk, “Jewish Reform Movement," 13.

87. Ibid., 23. 
"catafalques," another claimed that the new coffins did, indeed, look like catafalques, and that they had been introduced for the precise purpose of preventing the enlightened and wealthy from buying coffins from nonJews (such an incident had already occurred once). ${ }^{88}$ What remains unclear is whether this change was for the elite's own convenience, as it transformed the burial society in its own image, or was rather an attempt to incorporate certain modernizations into the society so that it would remain relevant to all Kiev Jews. ${ }^{89}$

Despite his role in the establishment of the Merchants' Synagogue, Lev Brodskii's own religious inclinations were somewhat idiosyncratic, like those of other Kiev Jews we have already seen. Indeed, it may have been just those inconsistencies in his own religiosity that convinced him of the importance of a new traditionalist synagogue in Kiev and, in general, of "old-time religion" as the foundation of Jewish life. Although Brodskii himself lived a life of libertinism, wrote E. E. Friedmann, he was concerned that the Jewish masses maintain their traditional religiosity and that their children be educated in hadarim, learning Bible, Talmud, the prayerbook, and psalms. When it came to communal funding for Jewish matters, he was interested only in Talmud-Torahs, ritual baths, and kashrut. ${ }^{90}$ The secular, acculturated life that bourgeois Jews wanted for themselves was deemed inappropriate for the masses. Clearly, they were anxious about the future of the "Jewishness" that they viewed as genuine and saw it as their duty to preserve traditional Judaism. It is interesting that philanthropy here played a central role in the maintenance of Jewish identity: by sponsoring traditional schools for the poor, well-to-do Jews could ensure that the authentic piety that they themselves had abandoned would be sustained. The role of the poor, then, was just as important in this transaction as that of the benefactors, for they - or their children - were charged with "being Jewish" as proxies for all Jews.

Brodskii was not the only member of the Jewish elite - especially those prominent in the communal leadership - who was anxious about growing secularization among the Jewish masses in the early years of the twentieth century. According to a communal critic writing in the short-lived

88. Ha-melits, no. 109 (May 13, 1894): 4-5.

89. We have no information on any innovations that might have been introduced in the design of the tombstones in Kiev. Cemeteries in Poland, and especially Warsaw's Jewish Cemetery, bear witness to the fact that "avant-garde" sepulchral monuments could be seen as early as the 1850 s. Monika Krajewska, $A$ Tribe of Stones: Jewish Cemeteries in Poland (Warsaw, 193), plate 95.

90. Friedmann, Sefer ba-zikbronot, 337. 
Yiddish newspaper Kiever vort under the pseudonym "Pedagogue," the members of the Schools Commission of the official communal body, known as the Representation for Jewish Welfare, demanded that an archaic, old-fashioned heder-style curriculum of prayers and psalms be preserved in communal schools. Although these men were themselves irreligious and did not teach their own children Yiddish, complained Pedagogue, they demanded piety from the Jewish poor and refused to be guided by the expertise of trained teachers. But the new generation of maskilim, activists in the Kiev branch of the OPE, the leading Jewish educational and cultural organization of the Russian Empire, were not much better, continued Pedagogue, despite their reputation for progressive thinking. ${ }^{91}$ Here too the bourgeoisie attempted to impose its vision of "authentic" yidisbkayt (Jewishness) on the poor who attended the schools it controlled. For example, when contemporary pedagogy dictated that children learn the Bible in abridged form, these "bourgeois maskilim" cried heresy and demanded that traditional methods of Jewish education be adhered to. While educational theory called for children to be educated in their mother tongue, the OPE activists threatened to cut school subsidies if teachers did not rid the curriculum of Yiddish and teach the prayerbook and psalms instead. ${ }^{92}$

As the example of the Brodskii brothers demonstrates, we cannot simply classify all wealthy merchants as acculturated and modernizing in their approach to religion; patterns of religious observance did not always break down according to the socioeconomic lines we might expect. According to Friedmann, most of the wealthy sugar merchants were "Orthodox" Jews who were knowledgeable about Torah, attended synagogue, and participated in traditional talmudic and midrashic study circles. ${ }^{93}$ (To confuse matters, this would not necessarily obviate taking on some of the trappings of imperial Russian society in dress and mannerisms: trimmed beards, European dress, and Russian speech.) Sholem Aleichem gives a fictional example of this kind of Kiev Jew in The Bloody Hoax in the form of Shlomo Familiant, a wealthy, "worldly merchant" who is at the same time a pious Hasid who disapproves of going without a hat, "a terrible sin," and wears the traditional "long kaftan and large prayer shawl,"94 Familiant is reminiscent of Ionna (Yonah) Zaitsev, one

91. OPE is the Russian abbreviation for the Society for the Dissemination of Enlightenment among the Jews of Russia, known in Hebrew as Hevrat marbe baskalab.

92. Kiever vort, no. 5 (January 6, 1910).

93. Friedmann, Sefer ba-zikbronot, 209.

94. Sholom Aleichem, The Bloody Hoax, trans. A. Shevrin (Bloomington, Ind., 1992), 72, 76-78. 
of Kiev's richest industrialists and a Hasid who remained strictly observant his whole life and apparently refused to attend the Choral Synagogue, as evidenced by his 1904 request for permission for a private chapel in his mansion. ${ }^{95}$ Zaitsev's claim that he was too old to walk to prayer houses in the two heavily Jewish neighborhoods of Kiev reveals that he preferred to walk several miles to Sabbath worship over a much shorter stroll to the nearer Choral Synagogue, which had been open since 1898. Conversely, those who we might view as the most opposed to acculturation were not necessarily so: the Hebrew press reported that the members of the household of the Hasidic Rebbe Yohanan of Rotmistrovka were all literate in Russian. This lax attitude came back to haunt the rebbe, however, as - according to one report, at least - when his son came to Kiev, he began to read the newspapers every day and eventually "ran off to study secular wisdom." 96

\section{THE EARLY TWENTIETH CENTURY}

By the early twentieth century, many Kiev Jews did not or could not maintain some of the most basic practices such as Sabbath and kashrut. Worsening economic conditions probably made it impossible for many to refuse to work on the Sabbath for fear of being fired, while for others the rapidly spreading ideologies of Jewish nationalism and socialism provided an alternative sense of Jewish identity and belonging. ${ }^{97}$ The 1907 annual report of the Kiev branch of the OPE remarked that shop clerks made up a very small proportion of the students in the organization's Saturday school for adults because many Jewish businesses were open on Saturday. ${ }^{98}$ The 1913 annual report of the Representation for Jewish Welfare remarked that "a significant portion of the more prosperous classes do not use kosher meat." 99 On the other hand, kashrut and Passover continued to be observed by the majority of Kiev's Jews, many of them poor; by the first decade of the twentieth century, there were three

95. RGIA f. 821 , op. 8 , d. 153 , 1. 85

96. Ha-melits, no. 262 (November 26, 1892).

97. Factories employing both Christian and Jewish workers, which by law had to be closed on Sunday, were usually open on Saturday. Thus, if a Jew insisted on keeping the Sabbath, he or she would have had to seek out a Jewish employer who hired only Jews. Many Jews in Kiev probably did not have this luxury. See Arcadius Kahan, "The Impact of Industrialization on the Jews in Tsarist Russia," in his Essays in Jewish Social and Economic History (Chicago, 1986), 41.

98. Kievskoe otdelenie Obshchestva rasprostraneniia prosveshcheniia mezhdu evreiami v Rossii, Otchet za 1907 god (Kiev, 1908).

99. Predstavitel'stvo po evreiskoi blagotvoritel'nosti pri Kievskoi Gorodskoi Uprave, Otchet za 1913 god (Vasil'kov, 1915), vii. 
subsidized kosher cafeterias in the city serving thousands of reducedprice or free meals every year, while Passover aid was still one of the community's major annual expenses. ${ }^{100}$ An advertisement in Kiever vort, a Yiddish newspaper unlikely to be read by acculturated Jews, screamed: "Kosher Food! Pure! Fresh! Inexpensive! A Jewish restaurant M. Likhter has opened at the newly improved hotel 'Louvre'! Groys-Vasilkover Gas, No. 6." 101 Tellingly, the most prominent (and often only) public face of Jewish Orthodoxy in Kiev was the "spiritual" rabbi Shlomo HaCohen Aharonson, who was something of a Maskil and had actually started a living in trade before turning to the rabbinate. ${ }^{102}$ The self-conscious secularism that was prevalent among activist-minded Jewish workers in some regions was less marked among Kiev Jews, and probably among Ukrainian Jews as a whole, because the Bund, the largest Jewish socialist party in the Russian Empire, was less of a force in the Russian South than in the more heavily industrialized regions of historical Lithuania and Congress Poland.

For some, abandoning certain religious practices or making changes in their religious life was not a choice. Government restrictions on the number of prayer houses in Kiev, for example, meant that Jews in some neighborhoods of the city did not have a synagogue where they could pray and bring up their children in an environment of traditional Jewish worship. In various petitions to the authorities for permission to hold services in private homes, groups of Jews bemoaned the deleterious effects that not attending synagogue had on their children; several memorials noted that there had been a drop in religiosity among the younger generation, which was falling into a life of immorality. ${ }^{103}$ Frequent expulsions of illegal Jews also meant that synagogues had to make do without religious professionals; High Holy Day services, for example, might have to be led by a tailor instead of a proper cantor. ${ }^{104}$

Comparisons of the Jewish population of Kiev and the number of le-

100. EE, s.v. "Kiev."

101. Kiever vort, no. 9 (January 11, 1910).

102. Yitshak Alfasi, Ha-bakham ha-mufla': Ha-rav Shlomo Ha-Cohen Abaronson, ha-rav ha-ra'shi ba-ri'shon shel Tel Aviv. Hayav u-fe alo (Tel Aviv, 1985), 18-19; "Toldotav," Ha-'arets (March 26, 1935) and "R. Shlomo Aharonson-Ha-rav," Ha'arets (March 15, 1936), both in Central Zionist Archives F30, file 230.

103. RGIA f. 821, op. 133, d. 705 ch. 1, ll. 253-253ob; RGIA f. 821, op. 8, d. 153, 1. 103ob.

104. YoTse"R, Mi-zeman le-zeman, mikhtav 'iti ha-yotse' le iti mi-bayit le-vayit beformat ka-zayit u-mi-hatser le-hatser MI-YoTo"eR LE-SHRETSER (Kiev, 1911) (Letter XIII: "Va-yishakehu, o neshikah be-yom huladeto"), 25. 
gally permitted prayer houses make clear that only a small percentage of Kiev Jews could squeeze into the usually small makeshift synagogues. What did everyone else do? Some Jews gathered illegally in their homes to worship on the Sabbath and festivals and were sometimes caught. ${ }^{105}$ Undoubtedly, some Jews did not attend such clandestine meetings for fear of arrest, others because they were a priori inclined to less consistent religious behavior and did not mind not attending communal worship. These individuals prayed at home or not at all.

Also of note is the wording of the petitions, which requested permission to meet during the autumn holidays as well as during the year on Sabbaths and festivals - but not every day or even on Mondays and Thursdays, arguably more important than other weekdays because of the reading of the Torah inserted into the service on those days. This may be because the petitioners, aware of the many restrictions on Jewish life in Kiev, did not want to ask for too much for fear of getting nothing. But it is a telling contrast to life in the small-town Jewish community, where the prayer house (often known as the house of study or beis medresh) was used not only on holy days but every day of the week. ${ }^{106}$

Russian Jews were not the only subjects in the empire to be influenced by secularizing forces. In just the period we have been examining, the Orthodox Church identified a need to "rechristianise society" as a response to creeping secularization and the loss of the loyalty of many educated (nominally Orthodox) citizens. ${ }^{107}$ Urban dwellers, especially those of the more comfortable socioeconomic classes, were known to be somewhat relaxed in their religious practice, and even peasants who migrated from the countryside in search of work "tended to be extremely lax in their religious observances when living in the city. Uprooted from village life . . . many workers also lost touch with their faith." ${ }^{108}$ This did not mean, of course, that such individuals lost their abiding reverence for the

105. Ha-melits, no. 6, (February 21, 1885): 88-93; Nedel'naia Khronika voskhoda, no. 43 (June 4, 1900): 9.

106. See, for example, Life Is with People, 51.

107. Simon Dixon, "The Church's Social Role in St Petersburg, 1880-1914," in Church, Nation and State in Russia and Ukraine, ed. G. A. Hosking (London, 1991), 167-92.

108. Rosamund Bartlett and Linda Edmondson, "Collapse and Creation: Issues of Identity and the Russian Fin de Siècle," in Constructing Russian Culture in the Age of Revolution: 1881-1940, ed. C. Kelly and D. Shepherd (Oxford, 1998), 191. See also the articles in Russian Orthodoxy under the Old Regime, ed. T. G. Stavrou and R. L. Nichols (Minneapolis, Minn., 1978). 
Orthodox Church, its saints, and symbols, but that their lives were no longer governed by the rhythm of the church and its rituals (bytovoe pravoslavoe). ${ }^{109}$ Like some Jews, however, once removed from the village or town setting where religious authority infused all aspects of life, they were not knowledgeable or zealous enough to maintain an observant lifestyle. And for members of the education and professional classes, the Church, sullied by its use as a tool of the state, was not a viable option for the expression of spirituality, as witnessed by the growth in popularity of spiritualism, mysticism, and evangelicalism in the last years of the empire. ${ }^{110}$ Given that, in the last years of the empire, some prominent rabbis attempted to enhance their power by forging an alliance with the government using the official Rabbinical Commission, it would not be surprising if some skeptical Jews began to see Orthodox Judaism in the same light. ${ }^{111}$

\section{CONCLUSION: CHANGES IN JEWISH RELIGIOUS PRACTICE IN A EUROPEAN CONTEXT}

The patterns we have observed in Kiev are far from unique among Russian Jewry or, indeed, among Jews across the European continent, though the chronological parameters differ from place to place depending on when a particular Jewish community began to experience modernization and acculturation. Whether in England, France, or Russia, the details of the condemnations were remarkably similar: wealthy communal leaders overseeing kosher slaughtering arrangements accused of not keeping kosher themselves; men charged with administering religious affairs and Jewish education criticized for rarely attending synagogue and for being indifferent to religion; and, among Jewish laypeople, a gradual transformation of religious practice. ${ }^{112}$

State-sponsored and/or lay-controlled rabbis also played a role in the

109. Gregory L. Freeze, "'Going to the Intelligentsia': The Church and Its Urban Mission in Post-Reform Russia," in Between Taar and People: Educated Society and the Quest for Public Identity in Late Imperial Russia, ed. E. W. Clowes, S. D. Kassow, and J. L. West (Princeton, N.J., 1991), 220.

110. Bartlett and Edmondson, "Collapse and Creation," 173-74.

111. Freeze, Jewish Marriage and Divorce, 248-51.

112. Todd M. Endelman, The Jews of Georgian England, 1714-1830: Tradition and Change in a Liberal Society (Philadelphia, 1979), 133; Phyllis Cohen Albert, The Modernization of French Jewry: Consistory and Community in the Nineteenth Century (Hanover, N.H., 1977), 103. For the case of Berlin, see Steven M. Lowenstein, The Berlin Jewish Community: Enlightenment, Family, and Crisis, 1770-1830 (New York, 1994). 
gradual transformation of religious practice throughout Europe. ${ }^{113}$ Many of the moderate reforms proposed by communal leaders, religious thinkers, or official rabbis did not differ from country to country. Decorum in the synagogue - including a ban on the auction of honors, dress codes, and the introduction of cantorial and choral music - often headed the list. Also important were professional rabbis with a secular education who could enlighten and inculcate morality in their congregants with sermons in the vernacular. Burial customs were another area of concern for reformers, who often wished to prolong the waiting period between death and interment or to make the funeral procedures more aesthetically pleasing through the use of hearses and other modern appurtenances. ${ }^{114}$

Among the Jewish masses, changes in religious practice often spread gradually from the cities to the towns and villages. The customs that hindered full social integration or economic advancement were often the first to be modified or dropped, especially rigorous observance of kashrut and Sabbath and festivals. ${ }^{115}$ Education also played an important role, as Jews educated in gymnasium or university rejected rituals they viewed as medieval or parochial and strove rather to become enlightened Europeans. Some also distanced themselves from their faith under the influence of contemporary philosophies hostile to Judaism. But as Todd Endelman points out with regard to the Anglo-Jewish elite, "it would ... be a mistake to view their casualness in religious matters solely as an attempt to escape their Jewishness. Although many wealthy Jews personally strayed from the path of traditional Judaism, they still maintained strong institutional ties to Jewish life." 116

When examining religious observance among Russian Jews in the late empire, the only pattern that emerges is the lack of any distinct pattern. Wealthy Jews might lead a life of libertinism but support traditional synagogues and educational systems; new arrivals to the city might drop some elements of religious practice but retain others, seemingly without

113. See, for example, Albert, Modernization, 53, 305; Paula E. Hyman, The Emancipation of the Jews of Alsace: Acculturation and Tradition in the Nineteenth Century (New Haven, Conn., 1991), 128.

114. See, for example, Hyman, Emancipation, 124; Albert, Modernization, 53; Todd M. Endelman, The Jews of Britain, 1656 to 2000 (Berkeley, Calif., 2002), 118.

115. Paula E. Hyman, "The Social Contexts of Assimilation: Village Jews and City Jews in Alsace," in Assimilation and Community: The Jews in Nineteenth-Century Europe, ed. J. Frankel and S. J. Zipperstein (Cambridge, 1991), 110-29; DeutschJüdisch Geschichte in der Neuzeit, ed. M. A. Meyer and M. Brenner (München, 1996), 2:159.

116. Endelman, The Jews of Georgian England, 135. 
rhyme or reason. But out of the idiosyncrasies and contradictions, we may indeed draw some conclusions. First, secularization was never a straight line from A to B, as the "loss of faith" trope common to so many of the memoir narratives of Jewish political activists would lead us to believe. Even those Jews whose full acculturation involved a distancing from traditional Jewish piety often retained some link, however tenuous, to religious observance - even if it was only "out of habit." On the other hand, the pressure of modernity was so great in the late imperial city that it might shake even the faith of pious Jews; whether consciously or unintentionally, customs and patterns that had previously been an unquestionable part of the fabric of daily life might now begin to be altered, however imperceptibly at first. (As Kees Bolle wrote, "secularization, as a process in which religious certainties are undermined, is something that is concealed at the time of its occurrence." ${ }^{117}$ ) The role of ideology in religious transformation has been stressed in discussions of Western and Central Europe and all but written off in the case of Eastern Europe, but a more balanced understanding is necessary. ${ }^{118}$ The gradual and often unselfconscious changes that we have witnessed in the Russian Empire often took place in lands where ideological reform was an important factor, when Jews responded not to the call of reforming rabbis but to shifts in the social and economic fabric of their lives. In other words, religion "lost its authority" 119 for many but did not lose its inherent value or appeal altogether. For its part, the evolving Jewish civilization in Eastern Europe was flexible enough to incorporate new expressions of Jewish identity that were products of the meeting of Russian and Jewish modernities.

117. Bolle, "Secularization as a Problem for the History of Religions," Comparative Studies in Society and History 12.3 (1970): 250. For more on secularization theory, see William H. Swatos Jr. and Kevin J. Christiano, "Secularization Theory: The Course of a Concept," Sociology of Religion 60 (Fall 1999): 209-28; Jeffrey K. Hadden, "Toward Desacralizing Secularization Theory," Social Forces 65.3 (1987): 587-611.

118. See, for example, David Sorkin, "Between Messianism and Survival: Secularization and Sacralization in Modern Judaism," Journal of Modern Jewish Studies 3.1 (2004): 73-86, in which the author discussed "modern Judaism" in terms of movements and ideologies but without reference to the phenomenology of Judaism. By doing so, the paradigm of the clear break between traditional religion and modernity that Sorkin applies to all of European Jewry might be less unambiguous. Perhaps, then, the sharp distinctions that have been drawn between Middle Eastern and North African Jewry and East European Jewry might in the future be reevaluated.

119. David Jan Sorkin, The Transformation of German Jewry, 1780-1840 (New York, 1987), 114 (emphasis added). 
This transformation was likely more similar than has been recognized to what David Sorkin has identified in Germany as "a complex pattern of integration which could also include the creation of new forms of identity and solidarity." ${ }^{120}$ Thus, the conclusion that reform in Russia "failed" because the confrontation of religion and modernity led to "secularist . . . forms of thought and behavior" ${ }^{121}$ is not entirely accurate because it fails to take into account the rich diversity of Jewish belief, practice, and identity in the Russian Empire.

True, Jews on the lower rungs of the socioeconomic ladder-without "exalted social aspirations" 122 and frequent personal interactions with non-Jews - were more likely to maintain traditional patterns of observance. Such traditionalism was certainly more widespread among Russian Jews than their coreligionists in Western Europe; as Stanislawski argues, "the vast majority [of Jews] responded to heterodoxy by gradually consolidating itself into an 'Orthodoxy': a self-conscious traditionalist society battling its enemies on their own ground." ${ }^{123}$ But the very fact that those Jews who now wished to maintain an observant lifestyle had to do so self-consciously is evidence of the momentous shift in Jewish life. Observance, once an intrinsic characteristic of premodern Jewish group life, now was - indeed, had to be - a choice. At the same time, as we have seen, it was not necessarily all or nothing: some customs might be retained while others abandoned, or one could slide (almost) unwittingly from a compromise with observance to outright transgression. And here, seemingly, is the paradox: an ever more self-conscious observance in some existed side by side with an unselfconscious blending of piety and laxity in others. Those who embraced innovations or changes in religious life did not always do so because they wished to distance themselves from Judaism, but rather in order to create a variety of Judaism that was compatible with modern urban life and an emerging Russian Jewish identity. This kind of ad hoc transformation is a "process that makes room for what is newly felt to be the real world." 124 Ideology as such had little role to play; more important were the day-to-day exigencies and contingencies of life in the busy city.

Trends that emerged first in the big cities tended to be harbingers of things to come elsewhere. Like stones thrown into a pond, events and

120. David Sorkin, "Religious Reforms and Secular Trends in German-Jewish Life: An Agenda for Research,” Leo Baeck Institute Year Book 40 (1995): 184.

121. Meyer, "The German Model of Religious Reform," 279.

122. Endelman, The Jews of Georgian England, 139.

123. Stanislawski, Toar Nicholas, 149.

124. Bolle, "Secularization as a Problem for the History of Religions," 251. 
innovations in Kiev and other urban centers rippled outward and were felt by Jews throughout the Pale of Settlement and indeed the entire empire. Moreover, the central questions of Jewish life of a century ago continue to have an impact on those of today, which means that understanding the dynamics of modernization and its impact upon religiosity is crucial not only for the historian but for many others within the contemporary Jewish world. In the fraught debate over forms and expressions of Judaism and Jewishness in today's world, whether in Israel or the Diaspora, in which both the piety and the secularity of past generations of Jews are called upon in the service of one ideology or another, contemplating the true complexity and nuances of religiosity of those past generations might provide the multidimensionality that is so lacking. 